\title{
WestVirginiaUniversity
}

THE RESEARCH REPOSITORY @ WVU

Graduate Theses, Dissertations, and Problem Reports

2015

\section{A Comparative Study of e-Tail Service Quality Scale in USA and India}

Usha K. Geddam

Follow this and additional works at: https://researchrepository.wvu.edu/etd

\section{Recommended Citation}

Geddam, Usha K., "A Comparative Study of e-Tail Service Quality Scale in USA and India" (2015). Graduate Theses, Dissertations, and Problem Reports. 5656.

https://researchrepository.wvu.edu/etd/5656

This Thesis is protected by copyright and/or related rights. It has been brought to you by the The Research Repository @ WVU with permission from the rights-holder(s). You are free to use this Thesis in any way that is permitted by the copyright and related rights legislation that applies to your use. For other uses you must obtain permission from the rights-holder(s) directly, unless additional rights are indicated by a Creative Commons license in the record and/ or on the work itself. This Thesis has been accepted for inclusion in WVU Graduate Theses, Dissertations, and Problem Reports collection by an authorized administrator of The Research Repository @ WVU. For more information, please contact researchrepository@mail.wvu.edu. 


\title{
A Comparative Study of e-Tail Service Quality Scale in USA and India
}

\author{
Usha K Geddam
}

Problem Report submitted to the

Benjamin M. Statler College of Engineering and Mineral Resources at West Virginia University in partial fulfillment of the requirements

for the degree of

Master of Science

in

Industrial Engineering

Rashpal Ahluwalia, Ph.D.

Feng Yang, Ph.D.

Majid Jaridi, Ph.D., Chair

Department of Industrial and Management Systems Engineering

Morgantown, West Virginia

2015

Keywords: e-Tailing, Service Quality, Factor Analysis

Copyright 2015 Usha Geddam 


\section{ABSTRACT \\ A Comparative Study of e-Tail Service Quality Scale in USA and India}

The purpose of this research is to measure the e-tail service quality of online retailers by considering survey responses from two different geographical locations, USA and India. This research focuses primarily on (i) Collecting data and performing factor analysis to refine initial scale items, developed by Qianqian, followed by reliability tests for checking the scale's validity by considering responses received from survey participants in two different geographical regions; (ii) Testing of hypothesis based on the construct of the scale items of the initial scale and the scale obtained in this research; (iii) Performing regression analysis to demonstrate the impact of factors on the overall e-tail service quality. Based on Qianqian's initial scale items, the questionnaire was slightly modified to accommodate changes related to mobile e-tailing. Data was collected and analyzed further through item analysis and exploratory factor analysis. The scale is later tested for its reliability and validity, followed by regression analysis. Results revealed a variation in scale parameters when a global sample is considered. This research is based on the assumption that the key to improving customers' online purchasing decisions is improving e-service quality, which in turn has a significant effect on transaction results. This research is purely theoretical, with basis on exhaustive literature review. 


\section{ACKNOWLEDGEMENTS}

I would like to my deepest appreciation to my committee chair Dr. Majid Jaridi for imparting his knowledge and expertise in this study. He continually and convincingly guided me throughout the research. I would like to thank my committee members Dr. Feng Yang and Dr. Ahluwalia for supporting me in my endeavor.

I am highly indebted to my family for their encouragement which helped me in the completion of my Master's degree. I feel tremendously grateful for the love and support of my parents throughout my education. My beloved and supportive husband, Shekhar, who was always by my side during times when I needed him the most. I thank my friends who were supportive and stood by me every time.

I finally want to thank my colleagues and staff of IMSE department. 


\section{Table of Contents}

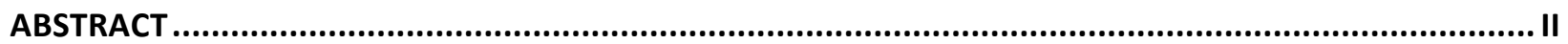

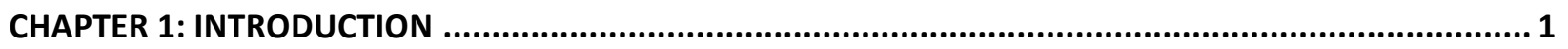

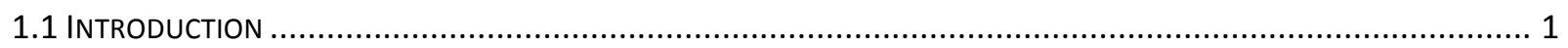

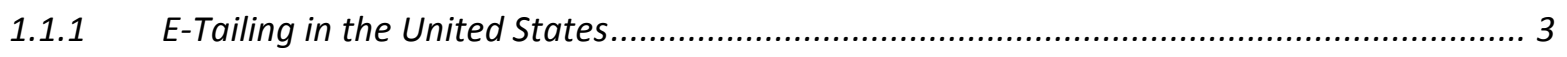

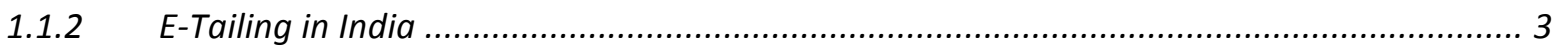

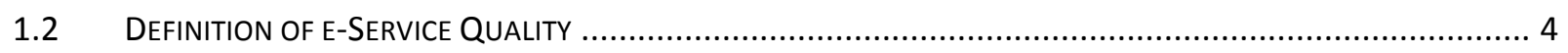

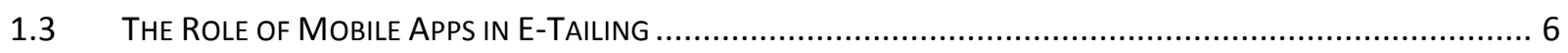

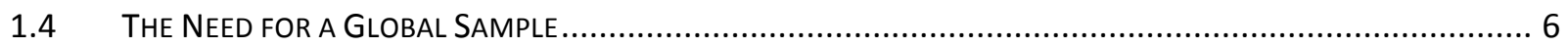

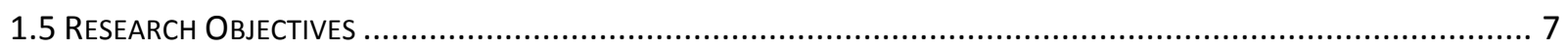

CHAPTER 2: LITERATURE REVIEW AND RESEARCH HYPOTHESES ................................................... 8

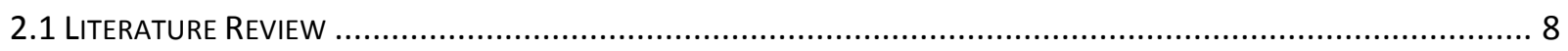

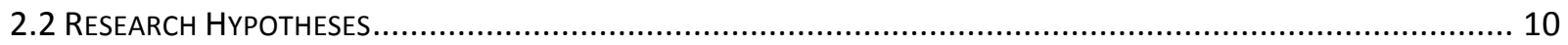

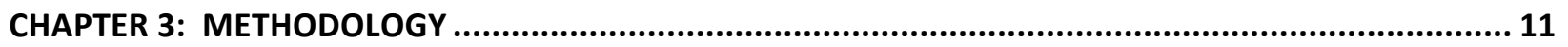

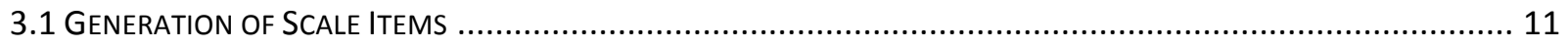

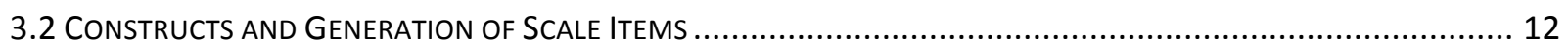

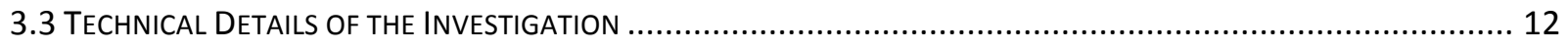

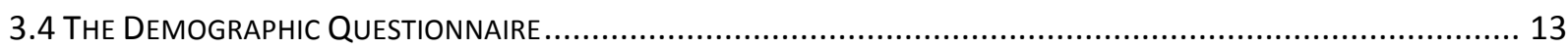

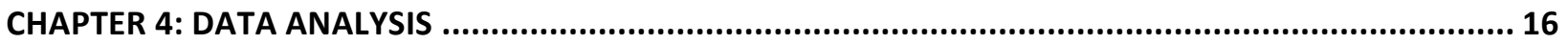

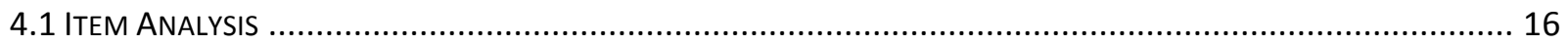

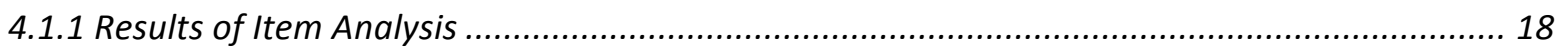

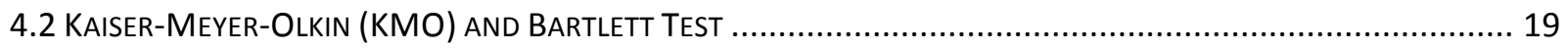

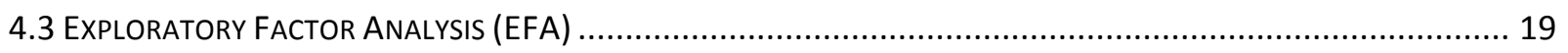

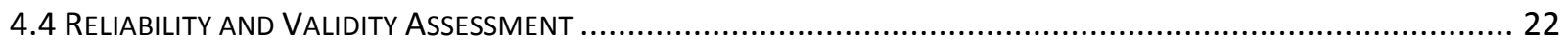

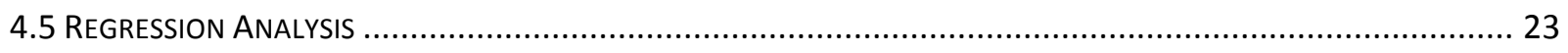

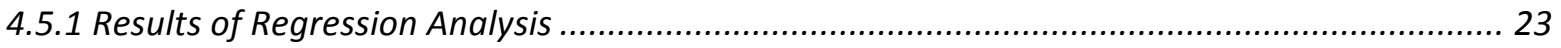

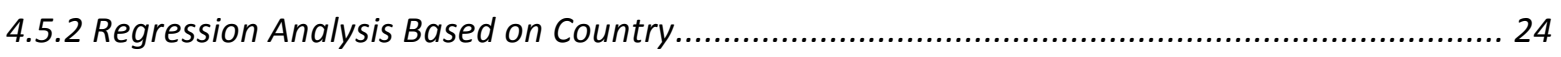

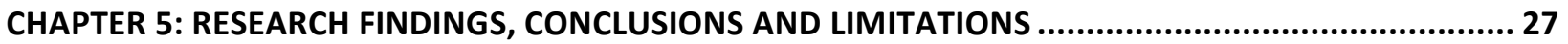

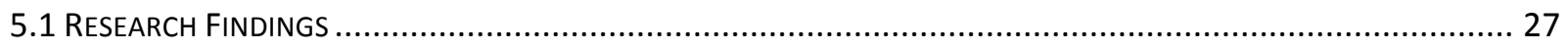

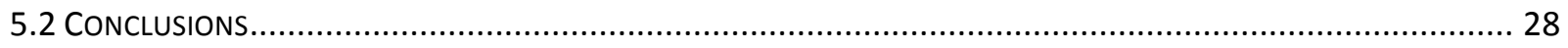

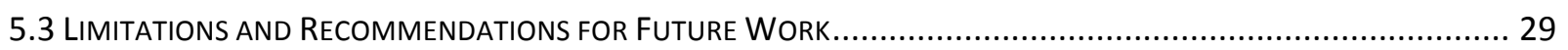

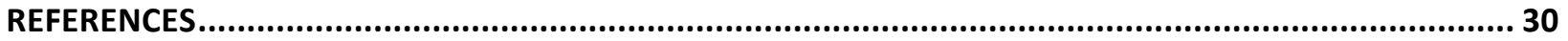




\section{LIST OF TABLES}

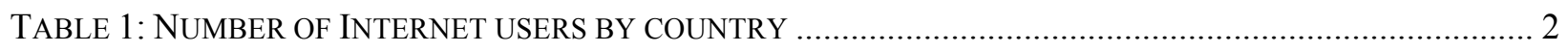

TABLE 2 : PREDICTED E-COMMERCE SALES IN THE UNITED STATES .......................................................... 3

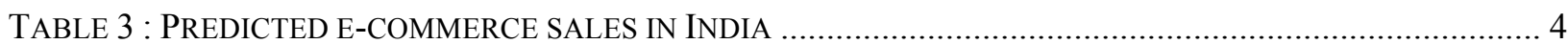

TABLE 4 : QUESTIONNAIRE CONTAINING SERVICE QUALITY ITEMS. .................................................... 11

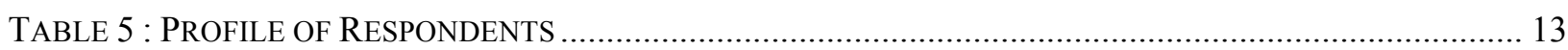

TABLE 6: SUMMARY OF ITEM ANALYSIS FOR THE ITEMS IN THE RELIABILITY SCALE.............................. 17

TABLE 7 : VALIDITY ANALYSIS OF FACTORS IN THE QUESTIONNAIRE …................................................... 19

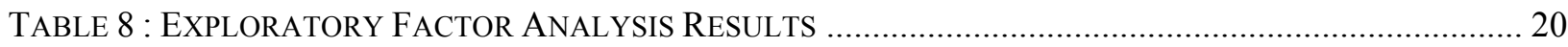

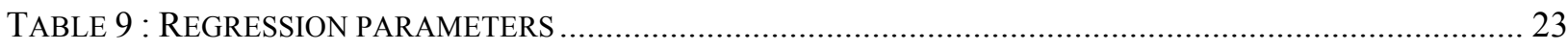

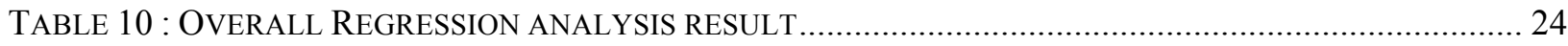

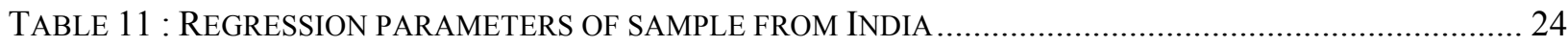

TABLE 12 : REGRESSION ANALYSIS RESULT OF SAMPLE FROM INDIA …............................................. 24

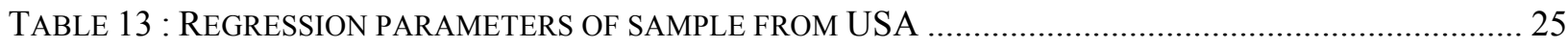

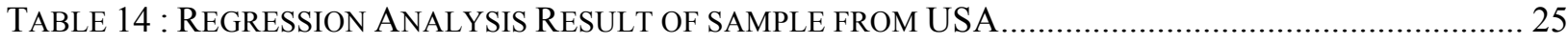

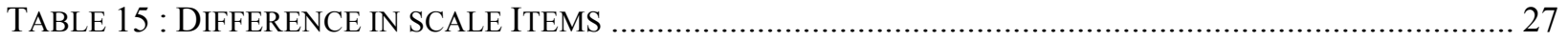




\section{LIST OF FIGURES}

Figure 1 : Demographic Results of THE RESPONDENTS BASED ON A) GENDER B) AGE C) SHOPPING FREQUENCY D) EMPLOYMENT STATUS E) COUNTRY OF RESIDENCE F) FREQUENTLY SHOPPED WEBSITES IN USA AND G) FREQUENTLY SHOPPED WEBSITES IN INDIA.......................................... 15

FIGURE 2 : GRAPH SHOWING THE AVERAGE OF SCALE ITEMS.............................................................. 16

FigURE 3 : THE DIAGRAM SHOWING 17-ITEM SCALE CATEGORIZED INTO 5 FACTORS .............................. 22 


\section{CHAPTER 1: INTRODUCTION}

\subsection{Introduction}

The customer is considered as a vital asset for any business organization. A business cannot afford to lose its customer base; this will lead to a decline in their market share and their profits. Service encounters as defined are the moments of interaction between a customer and a firm. Encounters may occur face-to-face in a service setting, over the phone, through the mail, or through Internet. "Each encounter is an opportunity for the firm to sell itself, to reinforce its offerings and to satisfy the customer. However, each encounter is also an opportunity to disappoint" (Allison Bettley, 2005)

The adaption of the Internet for commercial uses in the recent years has led to the emergence of e-commerce. Over the years, e-commerce has undergone rapid evolution. Ecommerce or electronic commerce is the purchasing, selling and exchanging of goods and services over computer networks. In fact, e-commerce was alive and well in business-to-business (B2B) transactions before the World Wide Web back in the 70s via EDI (Electronic Data Interchange) through VANs (Value-Added Networks). For China, developing e-commerce was an inevitable choice to penetrate the global market and bring an enormous rejuvenation to the nation (Zheng Qin, 2009). By using the Internet, customers can have the experience of browsing the websites to find merchandise or search merchandise information to compare prices.

Fornell, Johnson, Anderson, Cha and Bryant (1996) have developed an index called the American Customer Satisfaction Index, which determines the relationship between customer satisfaction and preceding consequences of customer satisfaction (Fen, Y. S. \& Lian, K. M. 2007). However, the model could not deal with handling service failure and how to gain back the trust of dissatisfied customers. There has been a prior recognition of customer satisfaction and service quality for occupying a crucial role for success in today's competitive market. Also, this has been the topic of extensive research for the past forty years. With the development of the Internet, e-commerce emerged in the past fifteen years and it is continuously growing globally. This phenomenon completely changed the face of business. E-commerce involves purchases through the Internet as well as the services provided through the electronic media such as online banking, travel, and advertising, whereas e-tailing refers to the purchase of goods online. E- 
tailing can be considered as a subset or a part of e-commerce. In this research, the primary emphasis is on improving the e-tail service quality. The initial scale developed for measuring service quality was SERVQUAL, which served as the platform on which the measurement of service quality takes place. However, the components of online shopping varied drastically to that of conventional retailing and hence, there was a development of a new scale E-S-QUAL.

Retail e-commerce sales worldwide predict the rise of online sales to be $\$ 1.077$ to $\$ 2.489$ trillion from 2013 to 2018 (E-marketer 2015). Digital buyers are increasingly looking beyond their borders to make purchases. From cross-border research in 2014, it was known that countries such as Mexico, Russia, Brazil, China, India and the United Arab Emirates plan to begin crossborder shipping as well as shop cross-border. About 1.21 billion digital buyers worldwide spent $\$ 1.455$ trillion on online or mobile purchases in 2014, which was up by $19.2 \%$ from 2013 (Emarketer 2015). More than one-third of the world's population lives either in China (1.3 billion) or India (1.2 billion), which together has about $30 \%$ of Internet users in the world (internetlivestats.com). Therefore, US e-tailing giants like Amazon launched their base in both China and India in a bid to expand the company globally. Table 1, below, shows the estimated number of Internet users in 2014 in several countries (PricewaterhouseCoopers, February 2015).

Table 1: Number of Internet users by country

\begin{tabular}{|c|c|}
\hline Country & Number of Users (millions) \\
\hline China & 641 \\
USA & 279 \\
India & 243 \\
Japan & 109 \\
Brazil & 107 \\
Russia & 84 \\
\hline
\end{tabular}

Global e-commerce expansion delivers a distinctive and unique opportunity for retailers to nurture and expand their revenue streams. International expansion of e-tailing is a prudent, intricate effort that has a huge influence on people, process, and technology. The quintessential work streams that are necessary for an e-commerce business expansion to a new marketplace are: 
defining the new market strategy, creating the store front and user experience, and building operations which include order fulfillment and managing international regulations.

\subsubsection{E-Tailing in the United States}

In the United States, the online retailing industry is progressing at a very fast rate. Online retailers aim to improve their sales by improving their websites and services. As online ecommerce gains ground, store-based retailers are having a reduced need for retail space they currently occupy. Online retailers are always on the lookout for profit through competitive means, which involve consumer attention and appreciation. In order to stay competitive, brands that sell apparel and consumer electronics have chosen to start online sales operations. The online sale of apparel and consumer electronics is one of the main reasons for the elevated ecommerce sales in the United States.

Today, the most defining factors for improved and ever increasing online sales in the United States is the adoption of smartphones, tablets, and other mobile Internet devices when searching, shopping or comparing prices. The continuous boost in technology led to better navigation and customer experience on the online sites, which in turn attracts more traffic to these sites. It has now become easier to shop online for the US shoppers due to the various advancements in mobile and tablet shopping improvements. Table 2 shows the predicted eCommerce sales in the USA till 2018 (Internetretailer.com).

Table 2: Predicted e-commerce sales in the United States

\begin{tabular}{|c|c|c|}
\hline Year & Sales in Billions (e-Marketer) & Sales in Billions (Forester Research) \\
\hline 2015 & $\$ 347.3$ & $\$ 325$ \\
2016 & $\$ 392.5$ & $\$ 355$ \\
2017 & $\$ 440.4$ & $\$ 385$ \\
2018 & $\$ 491.5$ & $\$ 414$ \\
\hline
\end{tabular}

\subsubsection{E-Tailing in India}

Although countries like USA and China achieved significant development in the field of online retailing, the notion of the Internet as a medium of shopping is still at its infancy in India. India's Internet population is growing fast, 190 million as of June 2014 and growing rapidly. 
Therefore, there was a growth of 35\% in online sales from $\$ 2$ billion in 2009 to $\$ 4.6$ billion in 2013, and it is estimated to reach $\$ 18$ billion in 2018. The growth is expected to occur due to consumer-led purchases in apparels, electronics, and accessories. There is a considerable amount of growth in online shopping, even though the penetration rate of the Internet in India is very low (only $8.4 \%$ of the population is online). Online firms in India concerning logistics, digital infrastructure, payment options and cultural factors face some major challenges.

India stands in third position globally for having the highest number of Internet users, after China with 620 million and the US with 275 million. By 2018, it is estimated that there will be 500 million Internet users in India, thereby making India the second-largest population of Internet users in the world (Alpesh Shah, January 2015).

A handful of domestic companies have successfully ventured into the e-commerce industry, which resulted in an increase in e-commerce. Domestic companies like Flipkart and Snapdeal rule the market, and multinational corporations like Amazon and China's Alibaba are competing hard. Table 3 shows the predicted e-commerce sales in India till 2018 (statista.com).

Table 3 : Predicted e-commerce sales in India

\begin{tabular}{|c|c|}
\hline Year & Sales in Billions (USD) \\
\hline 2015 & $\$ 7.69$ \\
2016 & $\$ 10.68$ \\
2017 & $\$ 14.18$ \\
2018 & $\$ 17.52$ \\
\hline
\end{tabular}

\subsection{Definition of e-Service Quality}

"Service quality through websites is an essential strategy to success, possibly more important than low price and web presence" (Parasuraman et al. 2002). The primary focus of research in the area of e-tailing has been in the enhancement of service quality to attract more customers to their business sites. "Service quality is the discrepancy between consumer's perceptions of services offered by a particular firm and their expectations about the firms offering such services" (Parasuraman, Zeithaml, \& Berry, 1988). Parasuraman et al. (2005, p. 217) described e-service quality as 'the extent to which a website facilitates efficient and 
effective shopping, purchasing and delivery'. In a way, customers also do contribute to the improvement of the quality of services when they evaluate the quality of service they receive. Although a direct human contact may not be required in an online environment, services are provided in the form of web design or package handling. Service rendered to the customer also includes the time of item delivery and return service of the merchandise. The summation of all the above parameters determines the customer's overall perceived service quality. The evaluation of service quality cannot be by the product's usage life or the rate of defects, which is the case for product quality. The fact that services are intangible and perishable (Parasuraman, Zeithaml, $\&$ Berry, 1988) makes it a challenging task to measure its quality.

The multiple item scale SERVQUAL developed by Parasuramen (1988) explores the various dimensions of service quality, which are reliability, responsiveness, assurance, empathy, and tangibles. Reliability refers to "the probability, at a given confidence level, that a component will perform its intended function for a specified mission time, without failure". According to Parasuramen, responsiveness is the firm's inclination to help its customers and provide quick service. Assurance refers to the expertise and reverence of the employees and their ability to instill trust and belief of their service to the customers. Empathy is the consideration given to every individual while providing service while tangibles refers to the accessories and facilities of the firm, which also includes the appearance of the personnel in the organization.

According to Wolfinbarger and Gilly (2002), the most dominant dimension of service quality is reliability, which is indicated to be a key predictor of customer satisfaction and quality and the second major indicator of loyalty and repurchase intentions at a website. According to Parasuraman (2005), reliability was associated with the technical functioning of the site, emphasizing on the site's availability and functionality.

In online shopping, the decision of the customer is judged by the information provided by the online retailer and their promises. If the service quality of the service provider is low or below the customer's expectation, the perceived service quality of the firm is lowered in the customer's point of view. This may lower the repurchase intention and may lead to negative word-of-mouth communication (Bitner, Brown, \& Meuter, 2000). Hence, there is always a crucial need for a firm to improve its service quality. As a result, studying the various factors that influence the service quality parameters is a challenge for firms investing in an online 
environment in an attempt to improve service quality and customer satisfaction. Improvement of service quality depends on the exploration and in-depth study of the various dimensions of service quality parameters.

\subsection{The Role of Mobile Apps in E-Tailing}

Mobile shopping is seeing phenomenal growth globally. The use of tablets and mobile phones for the purpose of online shopping has risen drastically over the past few years. This is due to the improvement in mobile shopping infrastructure such as smartphones, connectivity, mobile websites and apps. People have become more comfortable in ordering higher priced items online. According to E-Marketer, e-tail sales through smartphones and Tablets in the USA have accounted for $\$ 20.12$ billion and $\$ 35.3$ billion respectively in 2014 .

As mobile apps are being developed by most e-Commerce websites, smartphones and tablets are replacing personal computers for online shopping (E-commerce in India). As a result, the service quality parameters of both the website and app should be given due consideration. Therefore, in this research, the scale items where the term website is used in the original scale, is replaced by website/mobile app.

\subsection{The Need for a Global Sample}

According to Ladhari et al. (2011), the generalizability of the online e-service quality scales was limited, as they do not apply to a broader population of online users. Loiacono et al. (2002) have questioned their use of student samples: 'While these subjects are typical of a substantial body of web users, they are not a representative sample of all users.' Also, most of the respondents were not regular customers or users of the websites selected (Loiacono et al., 2002).

Also, most of the online surveys, which determined the validity of scales, took only US respondents into consideration. For example, all the respondents in Cai and Jun's (2003) study are from the Southwest and the Midwest regions in the US. Ranganathan and Ganapathy (2002) used a sample of respondents from Illinois. Seventy-four percent of the respondents in the Yang et al. (2004) study are US residents. The reasons for Internet use and the behavior of these participants may differ from those in other countries. Therefore, the research is aimed at getting samples from India and USA, which have the majority online population in the world next to China. 


\subsection{Research Objectives}

The primary focus of this research was to obtain a sample involving respondents from two different geographical locations USA and India. The reason for chosen samples from these countries is due to the fact that the mentioned countries have the highest percentage of Internet users worldwide next to China.

The objectives of this research are: (i) Collection of data and conduction of item analysis and factor analysis to refine the scale followed by reliability tests for checking the scale's validity by considering samples sizes from two different geographical locations in India and the USA; (ii) testing of hypothesis to establish the validity of the scale; (iii) performing the analysis of variance (ANOVA) to demonstrate the factors affecting e-tail reliability. A questionnaire containing items related to service quality parameters is developed based on the literature review and circulated to sample population in the USA and India. Data was collected from both countries (USA and India) and analyzed through exploratory factor analysis and regression analysis.

The research is structured as follows: the first part of the research focuses on the importance of e-service quality and highlights the emergence of mobile shopping and its significance in the increased e-tail sales. In the second part, data was collected from two geographical locations (USA and India) in the form of a survey and the scale is tested for dimensionality, reliability and validation in exploratory and terms. Item exploratory factor analysis was conducted to determine the scale validity. The third part of the research emphasizes the impact of the e-tail factors on the geographical location and discusses the managerial implications of the results, and concludes with the findings and limitations of the research. 


\section{CHAPTER 2: LITERATURE REVIEW AND RESEARCH HYPOTHESES}

\subsection{Literature Review}

Several studies have shown that by improving parameters such as service quality and customer satisfaction, a business could improve its overall financial performance (Babakus, Bienstock \& Van Scotter, 2004). Therefore, the key to higher profits is maximizing the service quality and thereby attaining a remarkable customer satisfaction.

Customer satisfaction has always been the most explored and significant topic of research for firms for several years. The first research, which was called measurement of customer satisfaction, started in the mid-1960s. Customer satisfaction can be viewed in two perspectives. From the viewpoint of antecedents, satisfaction is the response obtained due to the discordance between the expectations and anticipated performance of the product or service after its consumption (Tse \&Wilton, 1988). From the viewpoint of consequence, customer satisfaction is the prime reason for buying behavior and an asset for subsistence and development of any organization. From the viewpoint of dissatisfaction, Kondo (2001) addressed that customer satisfaction is lessening consumer complaints, which lead to dissatisfaction.

A multi-item scale called SERVQUAL was initially developed by Parasuraman to measure service quality (Parasuraman, Zeithaml and Berry, 1988). The items on the scale were divided into five categories, namely: tangibles, reliability, responsiveness, assurance and empathy. They have defined service quality from the antecedent's viewpoint as the disparity between the customer's expectation and the performance of the firm in providing the service. However, Carman (1990) proposed that expectations might not always be the indicators for measuring service quality. As a result, the scale was further modified into a 22-item SERVPERF scale. Neither one of SERVQUAL and SERVPERF could not encompass the entire services of stores that could provide a mix of merchandise and services. The service quality of a firm is the judgment of the consumer based on his experiences from each encounter with the company. Therefore, the object of concern for a service provider is the feedback given by the customer. 
In Electronic service quality, online shoppers browse the Internet for the items to purchase, add them to their shopping cart and submit the items to the store after a financial transaction. In some cases, the transaction could occur after the delivery of the item to the customer. The ever-increasing online sales over the past years indicate that a vast portion of customers prefer self-service as it saves time. At the same time, a lack of human contact is the biggest drawback. According to Cao (2002), an e-tailer's service can be categorized into two dimensions, namely pre-purchase services and post-purchase service quality. The services taken into consideration during a pre-purchase encounter includes ease of use, product selection, product information and website performance. On-time delivery, product representation, customer support and order tracking are the services provided by post-purchase. Any flaws in the pre-purchase services can lead to shoppers abandoning their shopping cart before they check out. The flaws may be due to poor website performance or insufficient product description. A shopping website needs to be fully functional with pictures, layouts, and additional links. The speed of the website is a matter of serious concern as time is an important factor for most online shoppers. Most of e-tail firms have a contract with the cargo carrier giants like UPS and FedEx for delivering the products. Customers have an option to choose the shipping method and the speed of shipping. The cargo carriers provide tracking services so that the customer could track the status of the shipment.

Online shoppers trust that the website could protect their personal information before they place any orders (Barnes \& Vidgen, 2002: Loiacono et al., 2002). Therefore, the dimension of reliability has a high significance which includes website reliability and customer service reliability (Wolfinbarger \& Gillly, 2002). Electronic service quality is defined as "the extent to which a website facilitates efficient and effective shopping, purchasing, and delivery" (Zeithaml, Parasuraman \& Malhotra, 2000, p. 11). The e-SQ scale developed by Parasumaran has been divided into two sets, namely, E-Core Service Quality Scale (E-S-QUAL) which has 22 items that measures the dimensions of electronic service quality like efficiency, fulfillment, system availability and privacy. Also, E-Recovery Service Quality Scale (E-RecS-QUAL) which consists of 11 items that measures three dimensions: responsiveness, compensation, and contact.

Wolfinbarger and Gilly (2003) proposed that a four-factor model may be utilized to structure online quality assessment which are: a) fulfillment/reliability, b) website design, c) 
customer service, and d) security/privacy. They have sub-divided these factors into two components: technical reliability and functional reliability. According to Wolfinbarger and Gilly (2003), the most dominant dimension of service quality is reliability, which is indicated to be a key predictor of customer satisfaction and quality and the second major indicator of loyalty and repurchase intentions at a website. Boshoff (2007) proposed a six-factor configuration, which was superior to the four-factor model proposed by Wolfinbarger, which established that reliability is the influential factor in the prediction of value perceptions. According to Parasuraman (2005), reliability was associated with the technical functioning of the site, emphasizing on the site's availability and functionality.

According to Zeithmal et al. (2002) online reliability was further technically considered as "technical reliability" which emphasizes that the factors which decide the service quality are five fold which are: 1) information reliability and content, 2) ease of use or usability, 3) privacy/security, 4) graphic style, and 5) fulfillment.

Zhao Qianqian and Qin Jin constructed a service reliability scale and further classified reliability into Product Congruity, Distribution Reliability, Information Reliability, Customer Service Reliability, Web technology Reliability. However, its limitations include a small sample size of 277 respondents, and the respondents are mainly students. Also, the geographical locations are centered in one region.

\subsection{Research Hypotheses}

According to several works in the literature, the main limitations of the consumer surveys are the limited sample size and constrained geographical location. Research data is obtained either from a small sample size, which may not be considerable enough to establish a valid statement, or the sample is always from a single geographical location. To address the question of the effect of geographical location on the scale, we develop the following hypothesis to be tested in this research:

$\mathrm{H}_{0}$ : Sample from different geographical locations affects the items of the scale.

$\mathrm{H}_{1}$ : Sample from different geographical location does not affect the items of the scale. 


\section{CHAPTER 3: METHODOLOGY}

\subsection{Generation of Scale Items}

In this study, the generation of scale items were based on Zhao et al. (2014) with minor changes to include mobile apps as mentioned earlier. The initial scale items were developed from Li and Suomi (2008), Stuart and Richard (2002) and Ding et al. (2011), which emphasize the various aspects of service quality. Table 4, below, shows the questions included in the questionnaire for the respondents to comment on.

Table 4 : Questionnaire containing Service Quality items.

\begin{tabular}{|c|l|c|l|}
\hline Variable & \multicolumn{1}{|c|}{ Measurement Item } & Variable & \multicolumn{1}{|c|}{ Measurement Item } \\
\hline$X_{1}$ & $\begin{array}{l}\text { The quality of product that I got is in } \\
\text { line with the business commitment. }\end{array}$ & $X_{13}$ & After sale service is excellent. \\
\hline$X_{2}$ & $\begin{array}{l}\text { The website/app provided detailed } \\
\text { information. }\end{array}$ & $X_{14}$ & Billing is accurate. \\
\hline$X_{3}$ & $\begin{array}{l}\text { The website/app provided accurate } \\
\text { information. }\end{array}$ & $X_{15}$ & Product delivery with right quantity \\
\hline$X_{4}$ & System runs smoothly. & $X_{16}$ & $\begin{array}{l}\text { The retrieval results meet my } \\
\text { requirement. }\end{array}$ \\
\hline$X_{5}$ & $\begin{array}{l}\text { The website/app keeps the sale } \\
\text { records accurately }\end{array}$ & $X_{17}$ & $\begin{array}{l}\text { Customer service representative showed } \\
\text { a sincere interest in solving problems. }\end{array}$ \\
\hline$X_{6}$ & $\begin{array}{l}\text { Product is delivered accurately and } \\
\text { timely. }\end{array}$ & $X_{18}$ & I get what I ordered from the site. \\
\hline$X_{7}$ & $\begin{array}{l}\text { Online payment was completed } \\
\text { safely and reliably. }\end{array}$ & $X_{19}$ & $\begin{array}{l}\text { The firm handled customer complaints } \\
\text { promptly. }\end{array}$ \\
\hline$X_{8}$ & $\begin{array}{l}\text { The product that I received was } \\
\text { represented accurately. }\end{array}$ & $X_{20}$ & The website/app has proper links. \\
\hline$X_{9}$ & $\begin{array}{l}\text { The website/app updates information } \\
\text { in a timely manner. }\end{array}$ & $X_{21}$ & $\begin{array}{l}\text { The website/app provided order } \\
\text { tracking. }\end{array}$ \\
\hline$X_{10}$ & $\begin{array}{l}\text { The product that I got is in line with } \\
\text { my expectation. }\end{array}$ & $X_{22}$ & $\begin{array}{l}\text { The products sent by the site are well } \\
\text { packaged. }\end{array}$ \\
\hline$X_{11}$ & $\begin{array}{l}\text { The products sent from the site are } \\
\text { not damaged }\end{array}$ & $X_{23}$ & Responded promptly to my enquiries. \\
\hline$X_{12}$ & $\begin{array}{l}\text { The return policy at this site is } \\
\text { reasonable }\end{array}$ & & \\
\hline & \multicolumn{2}{|c|}{} \\
\hline
\end{tabular}




\subsection{Constructs and Generation of Scale Items}

The questionnaire also included questions related to the demographic profile of the respondents in addition to the 23 scale items. It was distributed electronically to people from two different geographical locations (USA and India) through e-mail or social networks such as Facebook. The respondents were asked to choose the best option that describes their experience in each item scale by using a Likert scale which consists of 5 points ranging from $1=$ strongly disagree to $5=$ strongly agree. The option "not applicable" was included for all items of the scale in the survey, and was rarely used except for few customer service items.

\subsection{Technical Details of the Investigation}

Table 5, below, gives a brief insight into the general profile of the respondents. The eligibility criteria for the respondents of the survey are:

1. The respondents should be 16 years of age or older.

2. The respondents should be able to read and write in English.

3. Shoppers should have some prior experience in e-tail websites.

From a general point of view, the larger the sample size, smaller would be the sampling error. In such surveys, the percentage of respondents is expected to be as low as $20 \%$ to $30 \%$ (Best \& Kahn, 2003). Therefore, the online questionnaire was distributed to a considerable number of people to ensure a sufficient sample size. Respondents were entered into a sweepstakes (two prizes of $\$ 25$ Amazon gift card) as compensation for their participation, in an attempt to receive more responses.

The target population in this study were online shoppers from two countries India and USA. Therefore, responses received from other countries were considered invalid. An approximate number of 600 participants received the research questionnaire. Three hundred and forty-seven questionnaires were returned, out of which 68 were incomplete; therefore in this study, 282 valid respondent samples were obtained, 149 samples from the USA and 133 samples from India. Therefore, the overall response rate was $47 \%$. 


\subsection{The Demographic Questionnaire}

The demographic questionnaire requested information about the respondents' demographic attributes including gender, age, education levels, job status, country of residence, frequency of online shopping and their most frequently visited shopping website.

Table 5 : Profile of Respondents

\begin{tabular}{|c|c|c|c|}
\hline Classification & Groups & Frequency & Percentage (\%) \\
\hline \multicolumn{4}{|l|}{ Gender } \\
\hline & Male & 159 & $56.58 \%$ \\
\hline & Female & 122 & $43.42 \%$ \\
\hline \multicolumn{4}{|l|}{ Age (in years) } \\
\hline & $16-24$ & 123 & $43.77 \%$ \\
\hline & $25-34$ & 127 & $45.2 \%$ \\
\hline & $35-44$ & 22 & $7.83 \%$ \\
\hline & $45-54$ & 6 & $2.14 \%$ \\
\hline & 55 or over & 3 & $1.07 \%$ \\
\hline \multicolumn{4}{|l|}{ Employment Status } \\
\hline & Employed full-time & 139 & $49.47 \%$ \\
\hline & $\begin{array}{l}\text { Temporarily } \\
\text { unemployed }\end{array}$ & 15 & $5.34 \%$ \\
\hline & Student & 109 & $38.79 \%$ \\
\hline & Homemaker & 11 & $3.91 \%$ \\
\hline & Self-employed full-time & 5 & $1.78 \%$ \\
\hline & Retired & 2 & $0.71 \%$ \\
\hline \multicolumn{4}{|l|}{ Country of residence } \\
\hline & USA & 149 & $53.02 \%$ \\
\hline & India & 128 & $45.55 \%$ \\
\hline \multicolumn{4}{|c|}{ Highest level of education } \\
\hline & High school graduate & 24 & $8.57 \%$ \\
\hline & $\begin{array}{l}\text { Other post high school } \\
\text { vocational training }\end{array}$ & 1 & $0.35 \%$ \\
\hline & Associate Degree & 7 & $2.5 \%$ \\
\hline & Doctorate Degree & 8 & $2.85 \%$ \\
\hline & $\begin{array}{l}\text { College Degree (B.A, } \\
\text { B.S etc.,) }\end{array}$ & 102 & $36.42 \%$ \\
\hline & Master's Degree & 138 & $49.28 \%$ \\
\hline \multicolumn{4}{|c|}{ Frequency of shopping online } \\
\hline & More than once a day & 4 & $1.42 \%$ \\
\hline & Once a day & 1 & $0.36 \%$ \\
\hline & Several times a week & 34 & $12.1 \%$ \\
\hline & Several times a month & 115 & $40.93 \%$ \\
\hline & $\begin{array}{l}\text { Once a month or less } \\
\text { often }\end{array}$ & 127 & $45.2 \%$ \\
\hline
\end{tabular}


A summary of variables, frequencies and percentages are listed in Table 5. With respect to the most frequently visited website of the respondents, Amazon tops the list with 194 respondents (67.6\%), followed by Flipkart (14.29\%) and eBay (3.48\%). The sample contains 149 respondents $(51.92 \%)$ from USA and 133 respondents $(46.69 \%)$ from India. Therefore, the obtained sample eliminates the major limitation mentioned by Ladhari et al., which is centering the sample population to one region. Figure 1 shows the demographic results of all the respondents in the form of pie charts.

(a)

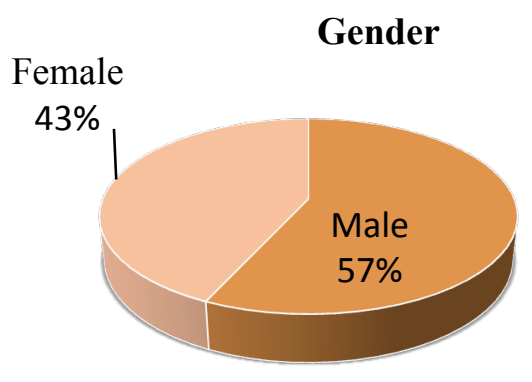

(b)

\section{Age}

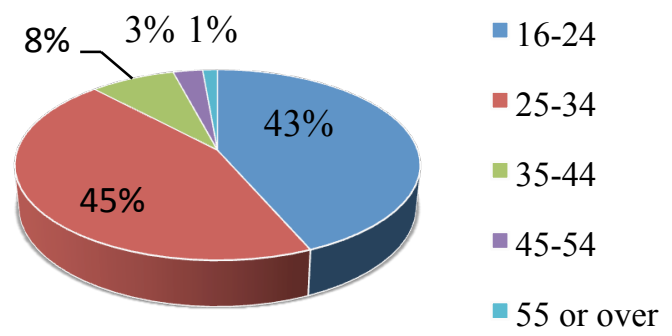

(d)
Shopping Frequency

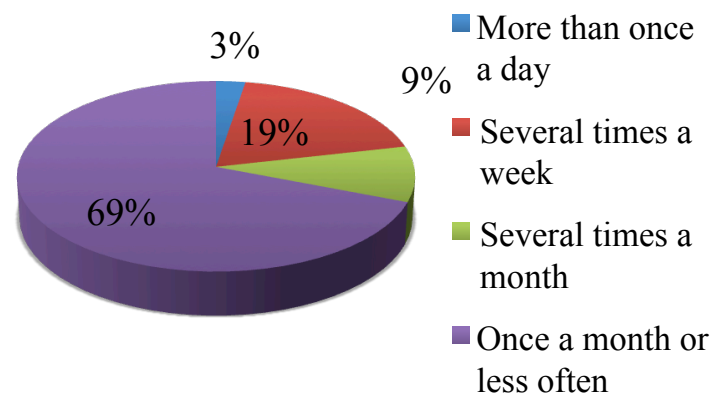

Employment status

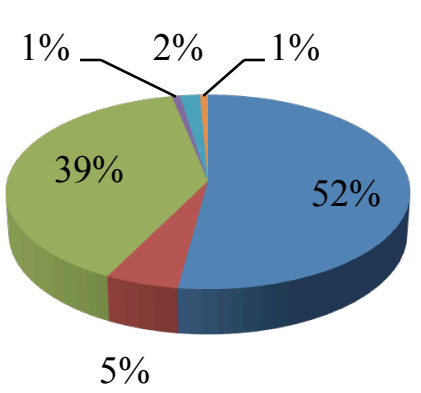

Employed full-

time

- Temporarily

unemployed

Student

- Homemaker

- Self-employed

full-time 

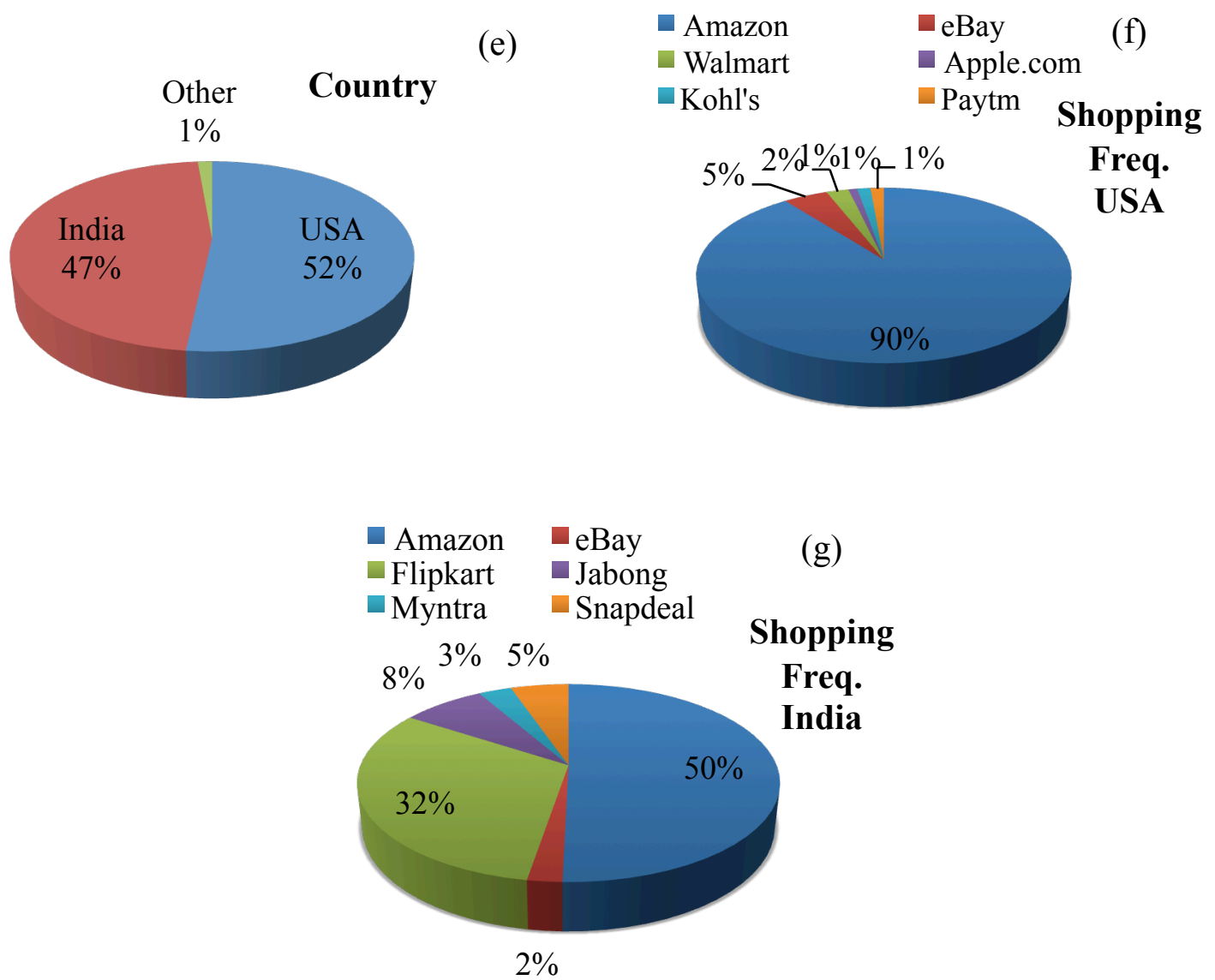

Figure 1 : Demographic results of the respondents based on a) Gender b) Age c) Shopping frequency d) Employment status e) Country of residence f) Frequently shopped websites in USA and g) Frequently shopped websites in India

As to the employment status, 144 respondents were employed full-time which accounted for $50.17 \%$ of the sample population followed by students, who accounted for $38.3 \%$ of the population, therefore eliminating the second limitation of Qianqian, whose sample population considered only students for the generation and validation of reliability scale. 


\section{CHAPTER 4: DATA ANALYSIS}

In this chapter, we discuss the results of statistical analysis and data collection for the reliability scale from the responses collected from the 282 participants from USA and India.

The target populations in this study were online shoppers from two countries. viz., India and USA. Therefore, responses from other countries are considered invalid and deleted for any further analysis. A "Not Applicable" (NA) response was defined as a missing value. Hence, mean replacement was used to calculate the missing values in our analysis (Kamakura \& Wedel, 2000).

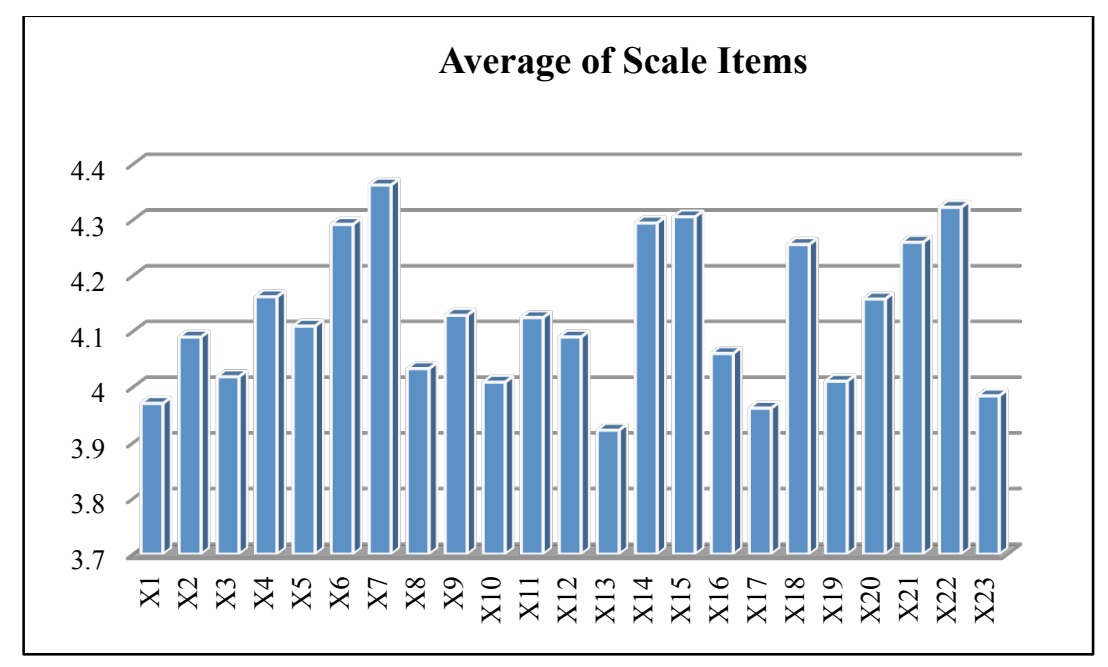

Figure 2: Graph showing the average of scale items

\subsection{Item Analysis}

Item analysis is used to provide an in-depth look at a data set. It indicates what items should be retained and what items should be deleted to increase the internal consistency of the questionnaire. Crook (2004) indicated that item analysis should first be performed reliably before a test can be declared as valid. In this research, three methods of Item Analysis is conducted to analyze each question: a) Critical-Ratio (CR), b) corrected item-total correlation and c) alpha if item deleted. They are described below.

a) Critical ratio (CR) value "determines the extent to which the scale you are testing correlates with a criterion" (Crook, 2004, p.104). Based on the feedback obtained from different 
correspondents, Critical Ratio (CR) of each item was computed using item analysis to determine the degree of despondency of each item to the scale.

Table 6: Summary of Item Analysis for the items in the Reliability scale.

\begin{tabular}{|c|c|c|c|c|c|}
\hline Item No. & Mean & $\begin{array}{l}\text { Standard } \\
\text { deviation }\end{array}$ & $\begin{array}{c}\mathrm{t} \text { test CR } \\
\text { value }\end{array}$ & $\begin{array}{c}\text { Corrected item } \\
\text { total } \\
\text { correlation }\end{array}$ & $\begin{array}{c}\text { Cronbach's } \\
\text { Alpha if } \\
\text { item deleted }\end{array}$ \\
\hline$X_{1}$ & 3.97 & .754 & 8.218 & .549 & .924 \\
\hline$X_{2}$ & 4.08 & .756 & 8.373 & .533 & .924 \\
\hline$X_{3}$ & 4.02 & .713 & 9.151 & .598 & .923 \\
\hline$X_{4}$ & 4.43 & .620 & 12.593 & .449 & .925 \\
\hline$X_{5}$ & 4.11 & .792 & 6.587 & .550 & .924 \\
\hline$X_{6}$ & 4.29 & .759 & 10.164 & .523 & .924 \\
\hline$X_{7}$ & 4.37 & .637 & 10.413 & .565 & .924 \\
\hline$X_{8}$ & 4.02 & .705 & 10.383 & .530 & .924 \\
\hline$X_{9}$ & 4.13 & .654 & 7.436 & .582 & .923 \\
\hline$X_{10}$ & 3.99 & .730 & 11.628 & .585 & .923 \\
\hline$X_{11}$ & 4.12 & .787 & 9.969 & .556 & .924 \\
\hline$X_{12}$ & 4.09 & .813 & 9.052 & .508 & .925 \\
\hline$X_{13}$ & 3.92 & .768 & 10.283 & .517 & .925 \\
\hline$X_{14}$ & 4.19 & .634 & 9.935 & .553 & .924 \\
\hline$X_{15}$ & 4.27 & .705 & 11.606 & .651 & .922 \\
\hline$X_{16}$ & 4.19 & .677 & 12.235 & .638 & .922 \\
\hline$X_{17}$ & 3.96 & .758 & 13.816 & .574 & .923 \\
\hline$X_{18}$ & 4.26 & .672 & 9.774 & .666 & .922 \\
\hline$X_{19}$ & 4.01 & .721 & 9.137 & .586 & .923 \\
\hline$X_{20}$ & 4.15 & .650 & 11.788 & .650 & .922 \\
\hline$X_{21}$ & 4.28 & .693 & 10.45 & .612 & .923 \\
\hline$X_{22}$ & 4.29 & .671 & 12.047 & .611 & .923 \\
\hline$X_{23}$ & 3.98 & .727 & 11.374 & .639 & .922 \\
\hline
\end{tabular}


The sample data is divided into two groups, namely high scoring and low scoring groups. The high scoring group consisted of the top $27 \%$ of the respondents, and the low scoring group contains the lowest $27 \%$. Independent sample T-tests were conducted to test the difference between the two groups. Based on the item analysis, if the value of $\mathrm{CR}$ is greater than 3 with significance level at $\mathrm{p}<0.05$, it means that the item has item discrimination (Zhao Qianqian and Qin Jin, 2014) and the item will be eliminated from the scale.

b) Alpha if item deleted is a measure of the scale's internal consistency. If a specific item in scale is deleted and thereby makes the Cronbach alpha go up, then deleting the item will result in an increase in internal consistency. The Cronbach alpha is a reliability coefficient that measures the internal consistency of the items. An alpha value close to 1 indicates high internal consistency in the data.

c) Corrected item-total correlation is the coefficient of correlation used to distinguish the related association of one scale item from the rest of the scale. If the coefficient is low, it means the internal consistency of the specific item does not measure with the others (Cronk, 2004). de Vaus suggests that anything less than 0.30 is a weak correlation for item-analysis purposes (de Vaus, 2004, Surveys in Social Research, Routledge, p.184), and that item should be removed. The summary of item analysis for the questionnaires in the survey is presented in Table 6, above.

\subsubsection{Results of Item Analysis}

The overall alpha for the 23 scale items was 0.927 , which is very high and indicates strong internal consistency among the 23 scale items. Essentially this means that respondents who tended to select high scores for one item also tended to select high scores for the others. Similarly, respondents who selected low scores for one item tended to select low scores for the other items in the questionnaire.

The Critical Value (CV) calculated from the two groups has produced a t-value greater than 2.6 for all the items in the scale. The item-total correlation values are all greater than 0.3 suggesting that there is a strong, positive correlation between the scores of one item and the combined scores of the total items in the scale. The value of Alpha if Item deleted of all the items 
were below the overall alpha value 0.927 . Therefore, no item was eliminated, and the data is suitable for factor analysis.

\subsection{Kaiser-Meyer-Olkin (KMO) and Bartlett Test}

Kaiser-Meyer-Olkin (KMO) test and Bartlett test of sphericity are conducted to determine whether the data is suitable for factor analysis. The KMO and Bartlett test of sphericity were conducted initially to determine the fitness of the data before conducting exploratory factor analysis. KMO test is used to measure the competence of data structure for factor analysis concerning the sample size. According to Kaiser (Kaiser, 1960), a value found in approximation to 1 is acceptable, while a value below 0.5 is unacceptable. Bartlett's test is used to test if ' $n$ ' samples are from a population, which have equal variances. Together, the tests reveal the competence of data for further proceeding with factor analysis.

According to the Principal Components Analysis with extraction method, the KaiserMeyer-Olkin (KMO) was 0.899. Using the Bartlett's Test of Sphericity, the approximate chisquare value was $(\mathrm{df}=253)$. All of the factors reached significance at level $.000(\mathrm{p}<.001)$, which indicates that the questionnaire is suitable for factor analysis. Table 7 shows the result for the KMO and Bartlett's test.

Table 7 : Validity Analysis of factors in the questionnaire

\begin{tabular}{|lll|}
\hline \multicolumn{2}{|c|}{ KMO \& Bartlett's Test } \\
\hline Kaiser-Meyer-Olkin measure of sampling adequacy & 0.899 \\
\hline \multirow{3}{*}{ Bartlett's Test of Spherecity } & Approx. Chi-square & 3411.516 \\
& df & 253 \\
& Sig. & .000 \\
\hline
\end{tabular}

\subsection{Exploratory Factor Analysis (EFA)}

In order to refine and reduce the number of items on the scale, several researchers have used Exploratory Factor Analysis (EFA). 
Table 8 : Exploratory Factor Analysis Results

\begin{tabular}{|c|c|c|c|c|c|c|c|}
\hline \multirow{2}{*}{ Dimensions } & \multirow{2}{*}{ Items } & \multicolumn{5}{|c|}{ Component } & \multirow{2}{*}{$\begin{array}{l}\text { Cronbach } \\
\text { alpha }\end{array}$} \\
\hline & & 1 & 2 & 3 & 4 & 5 & \\
\hline \multirow[t]{4}{*}{$\begin{array}{l}\text { Distribution } \\
\text { reliability }\end{array}$} & $\begin{array}{l}\mathrm{X}_{6} \text { Product is delivered } \\
\text { accurately and timely. }\end{array}$ & 0.762 & & & & & 0.873 \\
\hline & $\begin{array}{l}X_{15} \text { Product delivery with } \\
\text { right quantity }\end{array}$ & 0.799 & & & & & \\
\hline & $\begin{array}{l}\mathrm{X}_{21} \text { The website/app } \\
\text { provided order tracking. }\end{array}$ & 0.806 & & & & & \\
\hline & $\begin{array}{l}\mathrm{X}_{22} \text { The products sent by the } \\
\text { site are well packaged. }\end{array}$ & 0.825 & & & & & \\
\hline \multirow[t]{3}{*}{$\begin{array}{l}\text { Customer } \\
\text { service } \\
\text { reliability }\end{array}$} & $\begin{array}{l}\mathrm{X}_{13} \text { After sale service is } \\
\text { excellent. }\end{array}$ & & 0.706 & & & & 0.834 \\
\hline & $\begin{array}{l}\mathrm{X}_{17} \text { Customer service } \\
\text { representative showed } \\
\text { interest in solving problems. } \\
\mathrm{X}_{19} \text { The firm handled } \\
\text { customer complaints } \\
\text { promptly. }\end{array}$ & & $\begin{array}{l}0.816 \\
0.775\end{array}$ & & & & \\
\hline & $\begin{array}{l}\mathrm{X}_{23} \text { Responded promptly to } \\
\text { my enquiries. }\end{array}$ & & 0.793 & & & & \\
\hline \multirow[t]{3}{*}{$\begin{array}{c}\text { Product } \\
\text { Conformance }\end{array}$} & $\begin{array}{l}\mathrm{X}_{8} \text { The product that I } \\
\text { received was represented } \\
\text { accurately. }\end{array}$ & & & 0.87 & & & 0.687 \\
\hline & $\begin{array}{l}X_{1} \text { The quality of product } \\
\text { that I got is in line with the } \\
\text { business commitment. }\end{array}$ & & & 0.736 & & & \\
\hline & $\begin{array}{l}\mathrm{X}_{10} \text { The product that I got is } \\
\text { in line with my expectation. }\end{array}$ & & & 0.834 & & & \\
\hline \multirow[t]{3}{*}{$\begin{array}{l}\text { Information } \\
\text { reliability }\end{array}$} & $\begin{array}{l}\mathrm{X}_{2} \text { The website/app } \\
\text { provided detailed } \\
\text { information. }\end{array}$ & & & & 0.866 & & 0.797 \\
\hline & $\begin{array}{l}\mathrm{X}_{3} \text { The website/app } \\
\text { provided accurate } \\
\text { information. }\end{array}$ & & & & 0.582 & & \\
\hline & $\mathrm{X}_{14}$ Billing is accurate. & & & & 0.73 & & \\
\hline \multirow{2}{*}{$\begin{array}{l}\text { Web } \\
\text { technology } \\
\text { reliability }\end{array}$} & $\mathrm{X}_{4}$ System runs smoothly & & & & & 0.859 & 0.902 \\
\hline & $\begin{array}{l}\mathrm{X}_{7} \text { Online payment was } \\
\text { completed safely and } \\
\text { reliably. } \\
\mathrm{X}_{16} \text { The retrieval results } \\
\text { meet my requirement }\end{array}$ & & & & & 0.787 & \\
\hline $\begin{array}{l}\text { Eigen value } \\
\text { Total }\end{array}$ & & 3.01 & 2.8 & 2.28 & 2.12 & 2.02 & \\
\hline $\begin{array}{l}\text { explained } \\
\text { variance }(\%)\end{array}$ & & 17.7 & 34.2 & 47.6 & 60.1 & 71.9 & \\
\hline
\end{tabular}


In this study, an initial hypothesis that the factors in the scale are unrelated is assumed, and principal component analysis with Varimax rotation technique is applied. In factor analysis, a factor loading represents how much a factor explains a variable. Loadings can range from -1 to +1 . Table 8 shows the factor analysis results. Items are retained if (1) they load 0.5 or more on a factor or (2) do not load more than 0.5 on two factors (Hair et. Al., 1998). The items, which form the scale, would be removed if they bear either low or high factor loading values. SPSS software is used to conduct the Exploratory Factor Analysis.

The items in the scale are subjected to principal factor component factor analysis with a Varimax rotation which converged in 6 iterations and a relatively simple five-factor structure emerged. According to the results of factor analysis, we delete four items ( $\mathrm{X}_{11}$ : The products sent from the site are not damaged; $\mathrm{X}_{12}$ : The return policy at this site is reasonable; $\mathrm{X}_{5:}$ The website/app keeps the sale records accurately; $\mathrm{X}_{9}$ : The website/app updates information in a timely manner. $\mathrm{X}_{20}$ : The website/app has proper links; $\mathrm{X}_{18}$ : I get what I ordered from the site), which had factor loadings less than 0.53 . The scale items change after eliminating those items, so KMO testing and Bartlett's Test of Sphericity with the principal component analysis is conducted again, and the results of this test are consistent are consistent with our expectation. Through the purification process, the final scale which consists of 17 items on five factors is established.

The obtained factors which were named Product conformance, Distribution reliability, Information reliability, Customer service reliability and Web technology reliability, according to Zhao et al. Product Conformance means that all the features of a product that the customer gets is in line with the business's commitment and display. Hence, the product purchased should be intact with the promised features. Distribution reliability refers to the accuracy of the whole process from the allocation of goods or services from the firm to the customer. Information Reliability means that the product information provided by the online retailer to the customers is credible. Customer service reliability means that the service provided is compatible with the service that the online retailer promises. Web technology reliability refers to strong technology support, consistency and standardized navigation of the website, which also ensures safe and reliable online payment transactions. 


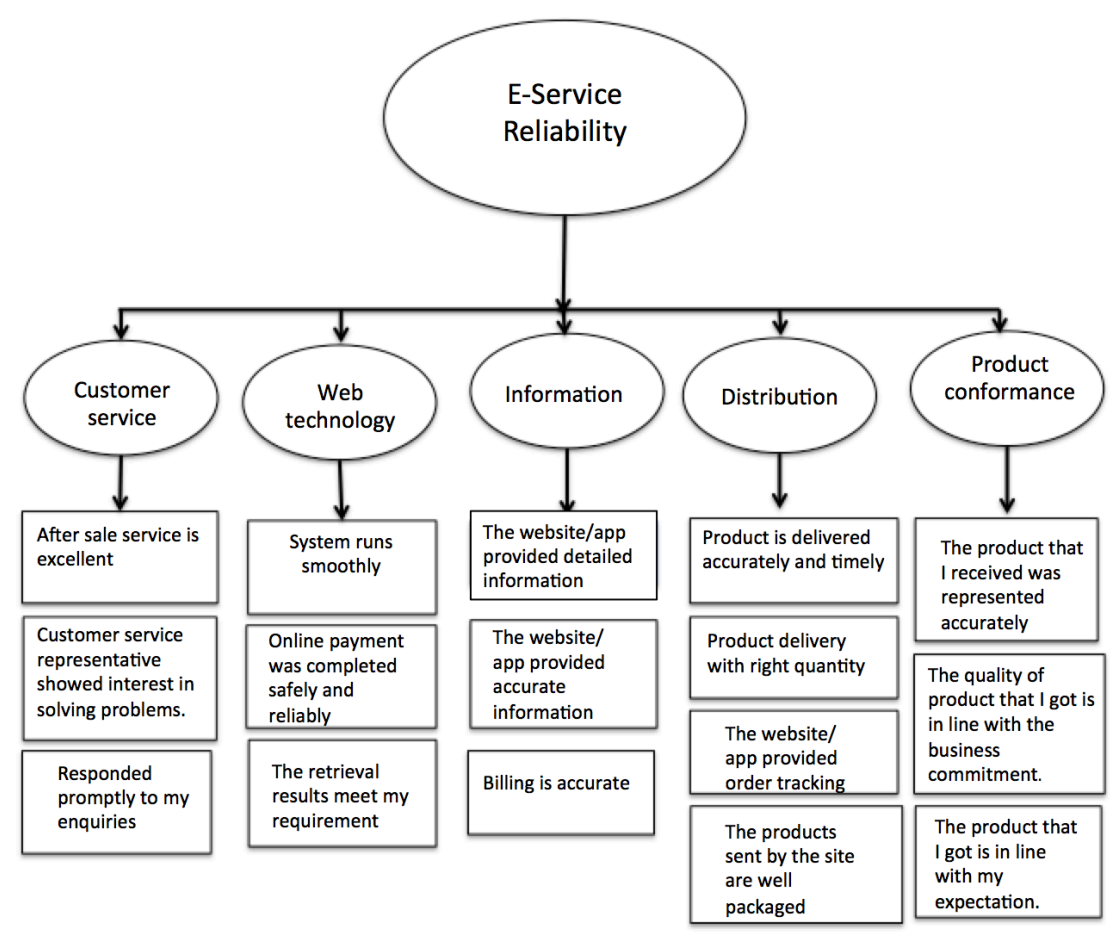

Figure 3 : Diagram showing 17-item scale categorized into 5 factors

\subsection{Reliability and Validity Assessment}

Factor reliability of the scale is estimated by computing its Croncbach Alpha. As shown in Table 8, the Cronbach alpha value of the five factors are $0.905,0.873,0.834,0.797$ and 0.687 respectively. All the values are above 0.7, which is the cut-off value for internal consistency. This indicates all the factors have high internal consistency and high reliability.

A validity test consists of content validity and structure validity test. Content validity test refers to "the suitability and consistency between the measurement items and all the correlative contents" (Zhao Qianqian and Qin Jin, 2014). In this research, the scale items were considered from the e-tail Reliability scale that has an established content validity. The construct validity of the scale is used to test the exploratory ability of the applied model. As there is a high total variance $(71.74 \%)$, high factor loadings (above 0.5$)$ and low cross-loadings on two or more factors (below 0.5), we can conclude that the scale has high construct validity. 


\subsection{Regression Analysis}

In order to estimate the impact of the five factors on the overall service quality, multiple regression analysis is performed. A multicollinearity test is performed for each variable to determine the degree of multicollinearity. The variance inflation factor (VIF) is calculated as a measure for multicollinearity. The maximum VIF value obtained is 1.625 , which is way less than 10 (the boundary for multicollinearity). To test serial correlation, Durbin-Watson (DW) statistic is calculated. Its value of 1.950 confirms that the model has no serial correlation.

\subsubsection{Results of Regression Analysis}

Regression Analysis is performed to study the significance of the factors on service quality. Therefore, the five factors obtained through EFA were entered as independent variables, and the perceived overall service quality is taken as the dependent variable. The results indicate that $\mathrm{R}^{2}=0.752$ and adjusted $\mathrm{R}^{2}=0.566$ which are above 0.4 . This indicates that the model has good fit. In order to access the degree of overall model fit, F-test is conducted, the value obtained is $71.9, \mathrm{p} \leq 0.000$. Therefore, we can conclude that the regression model is significant. The regression accounts to $56.6 \%$ of the total variance of the dependent variable $(\mathrm{F}=71.9$, $\mathrm{p} \leq 0.000$ ). Tables 9 and 10 show the results of regression analysis.

Table 9 : Regression parameters

\begin{tabular}{lccccc}
\hline Model & R-value & R square & Adjusted R Square & $F$ & $D W$ \\
\hline 1 & 0.752 & 0.566 & 0.558 & 71.905 & 1.960 \\
\hline
\end{tabular}

As shown in Table 10, three dimensions, namely, cCustomer service reliability, Product conformance and Information reliability have significant $t$-values and the standardized coefficient values are positive, thus making these three dimensions statistically significant. From the above data, customer service reliability has the most significant influence on overall service quality. 
Table 10 : Overall Regression analysis result

\begin{tabular}{|c|c|c|c|c|c|c|}
\hline \multirow[t]{2}{*}{ Independent variable } & \multicolumn{2}{|c|}{ Non-Standardized } & Standardized & t-value & Sig. & VIF \\
\hline & $\mathrm{B}$ & Standard Error & Coefficient Beta & & & \\
\hline (constant term) & .451 & .210 & - & 2.152 & .032 & - \\
\hline Web technology reliability & .186 & .050 & .182 & 3.689 & .000 & 1.541 \\
\hline Distribution reliability & .088 & .045 & .096 & 1.943 & .053 & 1.566 \\
\hline Customer service reliability & .304 & .043 & .336 & 7.038 & .000 & 1.451 \\
\hline Information reliability & .179 & .049 & .187 & 3.695 & .000 & 1.625 \\
\hline Product Conformance & .170 & .041 & .198 & 4.111 & .000 & 1.473 \\
\hline
\end{tabular}

\subsubsection{Regression Analysis Based on Country}

Considering data from responses obtained from individual countries like India and USA; Regression analysis is conducted in order to examine the variation in factor contribution to the overall service quality. The data is divided into two groups; one group pertaining to data from India and the other group consist of data from the USA. Tables 11 and 12 show the regression results of sample from India, while Tables 13 and 14 show the regression results of US sample.

Table 11 : Regression parameters of sample from India

\begin{tabular}{cccccc}
\hline Model & R-value & R square & Adjusted R Square & $F$ & $D W$ \\
\hline 1 & 0.774 & 0.599 & 0.584 & 37.994 & 1.990 \\
\hline
\end{tabular}

Table 12 : Regression Analysis Result of sample from India

\begin{tabular}{lllllll}
\hline Independent variable & \multicolumn{2}{l}{ Non-Standardized } & Standardized & t-value & Sig. & VIF \\
& $\mathrm{B}$ & Standard Error & Coefficient Beta & & & \\
\hline (constant term) & .744 & .279 & - & 2.664 & .009 & - \\
Product Conformance & .206 & .063 & .246 & 3.250 & .001 & 1.817 \\
Web technology reliability & .091 & .071 & .097 & 1.270 & .206 & 1.861 \\
Distribution reliability & .087 & .065 & .093 & 1.332 & .185 & 1.546 \\
Customer service reliability & .345 & .067 & .394 & 5.152 & .000 & 1.852 \\
Information reliability & .125 & .072 & .125 & 1.746 & .083 & 1.630 \\
\hline
\end{tabular}


The above results indicate that $\mathrm{R}^{2}=0.774$ and adjusted $\mathrm{R}^{2}=0.599$ which are above 0.4 shows the regression model has good fit. F-test produced a value of $37.9, \mathrm{p} \leq 0.000$, therefore, we can conclude that the regression model is significant. The regression accounts to $56.6 \%$ of the total variance of the dependent variable $(F=37.9, p \leq 0.000)$.

From the above results, we can conclude that Customer service reliability, Product conformance and Information reliability have significant t-values and the standardized coefficient values are positive, thus making these three dimensions statistically significant. Customer service reliability has the most significant influence on overall service quality.

Table 13 : Regression parameters of sample from USA

\begin{tabular}{cccccc}
\hline Model & R-value & R square & Adjusted R Square & $F$ & $D W$ \\
\hline 1 & 0.736 & 0.542 & 0.526 & 33.804 & 1.967 \\
\hline
\end{tabular}

Table 14 : Regression Analysis Result of sample from USA

\begin{tabular}{lcllllll}
\hline Independent variable & \multicolumn{2}{l}{ Non-Standardized } & Standardized & t-value & Sig. & VIF \\
& $\mathrm{B}$ & Standard Error & Coefficient Beta & & & & \\
\hline (constant term) & .240 & .329 & - & .729 & .467 & - \\
Product Conformance & .162 & .057 & .189 & 2.867 & .005 & 1.359 \\
Web technology reliability & .245 & .075 & .220 & 3.275 & .001 & 1.411 \\
Distribution reliability & .085 & .064 & .096 & 1.328 & .186 & 1.624 \\
Customer service reliability & .286 & .060 & .309 & 4.786 & .000 & 1.298 \\
Information reliability & .201 & .067 & .218 & 3.007 & .003 & 1.634
\end{tabular}

The above results indicate that $\mathrm{R}^{2}=0.736$ and adjusted $\mathrm{R}^{2}=0.542$ which are above 0.4 , hence, the regression model has good fit. F-test produced a value of 33.8, $\mathrm{p} \leq 0.000$, therefore, we can conclude that the regression model is significant. The regression accounts to $54.2 \%$ of the total variance of the dependent variable $(\mathrm{F}=33.804, \mathrm{p} \leq 0.000)$.

From the above results, we can conclude that Customer service reliability, Web technology reliability and Information reliability have significant t-values and the standardized 
coefficient values are positive, thus making these three dimensions statistically significant. Customer service reliability has the most significant influence on overall service quality.

According to the results, Web Technology reliability has scored a high t-value for the sample data obtained from the USA. This can be contributed to the higher advancement in web technology in USA compared to India. 


\section{CHAPTER 5: RESEARCH FINDINGS, CONCLUSIONS AND LIMITATIONS}

\subsection{Research Findings}

In this research, taking a global sample has altered the scale initially developed by Qianqian. While the initial scale consisted of 19 items grouped into five factors, the scale obtained by considering responses from two different geographical locations has produced a five factor 17 item scale.

Table 15 : Difference in scale Items

\begin{tabular}{|c|c|}
\hline Initial scale Items & Scale Items generated by research \\
\hline $\begin{array}{l}X_{1} \text { The quality of product that I got is in line } \\
\text { with the business commitment. }\end{array}$ & $\begin{array}{l}\mathrm{X}_{1} \text { The quality of product that I got is in line with the } \\
\text { business commitment. }\end{array}$ \\
\hline $\begin{array}{l}\mathrm{X}_{2} \text { The website/app provided detailed } \\
\text { information. }\end{array}$ & $\mathrm{X}_{2}$ The website/app provided detailed information. \\
\hline $\mathrm{X}_{4}$ System runs smoothly. & $\mathrm{X}_{3}$ The website/app provided accurate information. \\
\hline $\begin{array}{l}\mathrm{X}_{5} \text { The website/app keeps the sale records } \\
\text { accurately }\end{array}$ & $\mathrm{X}_{4}$ System runs smoothly. \\
\hline $\mathrm{X}_{6}$ Product is delivered accurately and timely. & $\mathrm{X}_{6}$ Product is delivered accurately and timely. \\
\hline $\begin{array}{l}\mathrm{X}_{7} \text { Online payment was completed safely and } \\
\text { reliably. }\end{array}$ & $\mathrm{X}_{7}$ Online payment was completed safely and reliably. \\
\hline $\begin{array}{l}\mathrm{X}_{8} \text { The product that I received was represented } \\
\text { accurately. }\end{array}$ & $\begin{array}{l}\mathrm{X}_{8} \text { The product that I received was represented } \\
\text { accurately. }\end{array}$ \\
\hline $\begin{array}{l}\mathrm{X}_{9} \text { The website/app updates information in a } \\
\text { timely manner. }\end{array}$ & $\begin{array}{l}\mathrm{X}_{10} \text { The product that I got is in line with my } \\
\text { expectation. }\end{array}$ \\
\hline $\begin{array}{l}\mathrm{X}_{10} \text { The product that I got is in line with my } \\
\text { expectation. }\end{array}$ & $\mathrm{X}_{13}$ After sale service is excellent. \\
\hline $\begin{array}{l}X_{11} \text { The products sent from the site are not } \\
\text { damaged }\end{array}$ & $\mathrm{X}_{14}$ Billing is accurate. \\
\hline $\mathrm{X}_{13}$ After sale service is excellent. & $\mathrm{X}_{15}$ Product delivery with right quantity \\
\hline $\mathrm{X}_{14}$ Billing is accurate. & $\mathrm{X}_{16}$ The retrieval results meet my requirement \\
\hline $\mathrm{X}_{15}$ Product delivery with right quantity & $\begin{array}{l}\mathrm{X}_{17} \text { Customer service representative showed a sincere } \\
\text { interest in solving problems. }\end{array}$ \\
\hline $\mathrm{X}_{16}$ The retrieval results meet my requirement & $\mathrm{X}_{19}$ The firm handled customer complaints promptly. \\
\hline $\begin{array}{l}\mathrm{X}_{17} \text { Customer service representative showed a } \\
\text { sincere interest in solving problems. }\end{array}$ & $\mathrm{X}_{21}$ The website/app provided order tracking. \\
\hline $\mathrm{X}_{18}$ I get what I ordered from the site & $\mathrm{X}_{22}$ The products sent by the site are well packaged. \\
\hline $\begin{array}{l}\mathrm{X}_{19} \text { The firm handled customer complaints } \\
\text { promptly. } \\
\mathrm{X}_{20} \text { The website/app has proper links } \\
\mathrm{X}_{23} \text { Responded promptly to my enquiries. }\end{array}$ & $\mathrm{X}_{23}$ Responded promptly to my enquiries. \\
\hline
\end{tabular}


There was a variation in the items in the scale as items $\mathrm{X}_{22}$ (The products sent by the site are well packaged), $\mathrm{X}_{21}$ (The website/app provided order tracking) and $\mathrm{X}_{3}$ (The website/app provided accurate information), which were deleted from the initial scale during factor analysis, were retained and had strong factor loadings in factor analysis. Table 15, above, lists the differences between the initial scale developed by Qianqian and the scale obtained in this research. However, from the overall regression analysis, it is proved that the three factors Customer service reliability, Product Conformance and Information reliability have major influence on overall service quality similar to the initial scale.

\subsection{Conclusions}

The research has successfully overcome the limitations about the sample imposed by Qianqian in the initial scale. The research sample consisted of respondents from varied employment status when compared to initial scale which had only students as the respondents. The research included respondents from two different geographical regions rather than centering in one region. By implementing item analysis, factor analysis and multiple linear analysis to test and analyze the survey data, we explored the five dimensions of online service quality by constructing a 17-item scale and also studied the impact of these five factors on overall service quality. We can conclude that geographical region plays an important role in the construction of a scale, as the items in the scale have changed significantly. Therefore, we reject the null hypothesis $\left(\mathrm{H}_{0}\right)$, which says that geographical location does not change the items on the scale and accept the alternate hypothesis $\left(\mathrm{H}_{1}\right)$, which proves that items in the scale vary.

Product conformance emerged as the most crucial factor in analyzing service quality. In an online environment, as the customers can only view the products online and can't touch them, an accurate and detailed description of the product is of utmost importance to any customer. Therefore, the firm has to make sure that the product description is good, and the delivered product fits the description.

Customer service reliability has the second most significant impact on overall service quality. Customers may need help from time to time about a product. By strengthening the human resource management, a firm can deal with all problems posed by customers quickly and 
accurately. In order to enhance its business, a firm should focus on improving its customer service.

Information reliability emerged as the third most important dimension of service quality. The firm should provide true and valid information about the product. As per the results from regression on data from the USA, Web technology reliability played a major role followed by information reliability. This can be associated by rapid and advanced development of information technology in USA. According to the survey, nearly $45 \%$ of the respondents from USA shop several times a month, whereas $50 \%$ of respondents from India shop once a month or less often. Hence, we can conclude that the website attributes which define web technology reliability in India need enhancement. A firm should undertake to improve its web technology and consider choosing high-quality logistic provider to develop an excellent service environment for online shopping.

\subsection{Limitations and Recommendations for Future Work}

The study is not confined to a single e-tail firm, as the respondents had the option of rating their favorite e-tail firm. The percentage of the respondents is low as $47 \%$, which led to a small sample size. For $95 \%$ confidence level and $\pm 4 \%$ confidence interval, a sample size of 600 would be needed. In future study, the sample size of the required number of respondents can be determined. The study does not adopt a random sampling method as there is no complete list of online shoppers, instead an online survey was conducted by means of sending questionnaires through e-mail and via social media networks like Facebook. Hence, the sample may not represent the entire population.

In the future, increasing the sample size and including samples from more than two different geographical locations can lead to better generalizability of the results. 


\section{References}

1. Alpesh Shah, Nimisha Jain and Shweta Bajpai, India@Digital.Bharat, Internet and Mobile Association of India, January 2015.

2. Babakus, Bienstock \& Van Scotter, Linking Perceived Quality and Customer Satisfaction to Store Traffic and Revenue Growth, Journal of the Decision Sciences Institute, 35 (4), 2004.

3. Barnes, S.J., Vidgen, R.T., 2002. An integrative approach to the assessment of Ecommerce quality. Journal of Electronic Commerce Research 3 (3), 114-127.

4. Best, J. W., \& Kahn, J. V. (1998). Research in education (8th ed.). Boston: Allyn and Bacon.

5. Bitner, M. J., S. W. Brown, M. L. Meuter. 2000. Technology infusion in service encounters. Journal of Academy of Marketing Science 28 (1): 138-149.

6. Boshoff C. A., 2007. Psychometric assessment of E-S-QUAL: A scale to measure electronic service quality. Journal of Electronic Commerce Research 1(8): 101-114.

7. Cai, S., Jun, M., 2003, Internet users' perception of online service quality: a comparison of online buyers and information searchers, Managing Service Quality 13 (6), 504-519.

8. Cao, Y. (2002). Three essays on e-tailer's pricing services and customer channel usage in the Internet market place. Dissertation Abstracts International, 63(7), 122 A. (UMI No. 3058390).

9. Carman, J. M. (1990). Consumer perception of service quality: An assessment of the SERVQUAL dimensions. Journal of Retailing, 66(1), 33-55.

10. Gilbert A Churchill Jr., A Paradigm for Developing Better Measures of Marketing Constructs. Journal of Marketing Research, Feb 1979, p.64.

11. Ding D. X., P. J-H. Hu, O. R. Sheng. 2011. E-SELFQUAL: A Scale for Measuring Online Self-service Quality. Journal of Business Research 64(5): 508-515.

12. Fen, Y.S. \& Lian, K.M. (2007). Service quality and customer satisfaction: Antecedents of customer's re-patronage intensions, Sunway Academic Journal, 4(1), 59-73.

13. Fornell, C., Johnson, M. D., Anderson, E. W., Cha, J., \& Everitt Bryant, B. (1996). Growing the trust relationship [Electronic version]. Journal of Marketing, 60(4), 7-18.

14. Hair, Joseph F., Ralph E. Anderson, Ronald L. Tatham, and William C. Black (1998), 
Multivariate Data Analysis, 5th ed. Upper Saddle River, NJ: Prentice Hall.

15. Kaiser H F. The application of electronic computers to factor analysis. Educ. Psycho! Meas. 20:141-51, 1960.

16. Kline, R.B. (2011). Principles and practice of structural equation modeling, $3^{\text {rd }}$ Ed. New York: The Guilford Press.

17. Kondo, Y. (2001). Customer satisfaction: How can I measure it? Total Quality Management, 12 (7), 867-872.

18. Li H., R. Suomi. 2008. Dimensions of e-service quality: an alternative model. $2^{\text {nd }}$ International Conference on Future Generation Communication and Networking 29-35.

19. Loiacono, E.T., Watson, R.T., Hoodhue, D.L., 2002. WEBQUAL: measure of web site quality. Marketing Educators Conference: Marketing Theory and Applications 13, 432437.

20. Mary Jo Bitner, Evaluating Service Encounters: The effects of Physical Surroundings and Employee Responses, 1990.

21. Parasuraman A., V. A. Zeithaml, A. Malhotra. 2005. E-S-QUAL: A multiple-item scale for assessing electronic service quality. Journal of Service Research 2: 213-233.

22. Parasuraman A., V. A. Zeithaml, L. L. Berry. 1988. SERQUAL: A multiple-item scale for measuring consumer perception of service quality. Journal of Retailing 64: 12-40.

23. Ranganathan, C., Ganapathy, S., 2002. Key dimensions of business-to-consumer web sites. Information and Management 39, 457-465.

24. Retrieved from http://www.emarketer.com/corporate/coverage\#/results/1259, Worldwide Retail Ecommerce: The eMarketer Forecast for 2015.

25. Internet live stats. (2014, July 1). Retrieved from http://www.internetlivestats.com/internet-users-by-country/

26. Riadh Ladhari, Developing e-service quality scales: A literature review, Journal of Retailing and Consumer Services 17 (2010), 464-477.

27. Stuart J., T. V. Richard. 2002. An integrative approach to the assessment of e-commerce quality. Journal of Electronic Commerce Research 3 (3): 114-127.

28. Tabachnick, Barbara G., and Linda S. Fidell. 2007. Using multivariate statistics. Boston: Pearson/Allyn \& Bacon. 
29. Tse, D. K., \& Wilton, P. C. (1988). Models of consumer satisfaction formation: An extension. Journal of Marketing Research, 25 (2), 204-212.

30. Wolfinbarger M., M. C. Gilly. 2003. eTailQ: Dimensionalizing, measuring and predicting e-tail quality. Journal of Retailing 79 (3): 183-198.

31. Yang, Z., Jun, M., Peterson, R.T., 2004. Measuring customer perceived online service quality: scale development and managerial implications. International Journal of Operations and Production Management 21 (11), 1149-1174.

32. Zeithaml V. A., A. Parasuraman, A. Malhotra. 2002. Service Quality Delivery through Web Sites: A Critical Review of Extant Knowledge. Journal of the Academy of Marketing Science 30 (4): 362-75.

33. Zeithaml, Parasuraman \& Malhotra, Service Quality Delivery through Web Sites: A Critical Review of Extant Knowledge, 2002, p. 11.

34. Zhao, Qianqian, and Jin Qin. "Exploratory study of e-tailing service reliability dimensions." Production and Operations Management Society $25^{\text {th }}$ Annual conference, 2014.

35. Cronk, B. C. (2004). How to use SPSS: A step-by-step guide to analysis and interpretation (3rd ed.). Glendale, CA:Pyrczak.

36. Operations Management: A Strategic Approach, Allison Bettley, David Mayle, Tarek Tantoush-2005- Business Economics.

37. Vertical Web Media. (2015). internetretailer. Retrieved November 10, 2015, from portal to e-commerce intelligence: https:/www.internetretailer.com/trends/sales/us-ecommerce-sales-2013-2017/

38. PricewaterhouseCoopers (PwC). (2015, February). eCommerce in India: Accelerating growth. Retrieved from http:/www.pwc.in/assets/pdfs/publications/2015/ecommerce-inindia-accelerating-growth.pdf.

39. statista. (2015). Retrieved on November 10, 2015, from http://www.statista.com/statistics/289770/india-retail-e-commerce-sales/

40. Vaus, D. D.,Surveys in Social Research (5 ed.). Routledge, 2004.

41. Zheng Qin, Introduction to E-commerce, Tsinghua Univ. Press, Beijing, 2009. 
